\title{
The Influence of Sailor Moon for Indonesian Girls in the 90s
}

\author{
Ranny RASTATI(ラニー・ラスタティ: Researcher of Research Center for Society and Culture, \\ National Research and Innovation Agency, Republic of Indonesia) \\ 四 ranny.rastati@gmail.com
}

(インドネシア)インドネシア共和国国立研究革新庁社会文化研究センター研究員。『インドネシアにおけるコスプレ・ツー リズム』(の本の章コンテン゙シツーリズム：メディアを横断するコンテンツと越境するファンダム』(札幌：北海道大学出版 会. 2021)、「Virtual Tour: Tourism in the Time of Coronaı (スラカルタ：Atlantis Press, 2020)、「Akatsuki Afkar : Creative Dawah (Preaching Islam) through Cosplay in Indonesiaı (ホノルル : Japan/Japanese Studies through a Southeast Asian Lens. University of Hawaii at Manoa, 2019)、「Islamic Manga : An Introduction (ジャカルタ : ASJl, 2016)、「From Japanese Soft Power To Hijab Cosplay」 (ジャカルタ : JMB LPI Vol 17. No 3. 2015) など。

\section{The Influence of Sailor Moon for Indonesian Girls in the 90s}

Sailor Moon is one of the most iconic classic anime for Indonesian audiences, especially the generation whose childhood was in the 90s. After more than two decades since its premiere, Sailor Moon still has loyal fans today. Although it has not been broadcast on Indonesian national television since the late 90s, the distribution of Sailor Moon products, both original and fake, still happen, such as clothes, bags, makeup, and knick-knacks. The question is, how does the Sailor Moon influence Indonesian girls in the 90s, so its popularity still lasts today? Based on observation and several in-depth interviews, this paper finds several arguments. First, Sailor Moon appears amid many male superheroes, giving an insight that female can be the hero of the world. Second, the audience finds the alter ego in the Sailor Moon character. Three, the values of Sailor Moon that provide understanding in shaping one's character, such as friendship, the importance of teamwork, and pursue a dream. In addition, Sailor Moon also introduced several issues such as sexual orientation, gender identity, and portrayal of body image. Nevertheless, Sailor Moon is considered a "childhood friend," which shapes a girl's childhood dreams; believed that everyone can be anything and found "the moon power" in themselves.

Keywords Sailor Moon(セーラームーン), Manga(マンガ), Anime(アニメ),

Popular Culture(大衆文化), Indonesia(インドネシア) 


\section{Introduction}

Indonesian children who spent their childhood in the 90s are familiar with the Sailor Moon 美少女戦士セーラームーン series. At the time, Sailor Moon, both manga and anime, was hugely popular especially among elementary and middle school girls. "On behalf of the Moon, I'll punish you!" was Sailor Moon's most famous catchline which became the most iconic one. As a young girl back in the 90s, Sailor Moon was one of my favorite manga/anime back time. Especially when Usagi Tsukino shouted the words "Moon prism power, make up" to transform into Sailor Moon, it felt like I was also transformed into a superhero.

Sailor Moon manga was published in Indonesia in 1994-1997 with two versions which are black and white and full color. One year after the Sailor Moon manga was published, the anime version aired on the national channel named Indosiar in 1995. From the five seasons of Sailor Moon anime which are Pretty Soldier Sailor Moon, Sailor Moon R, Sailor Moon S, Sailor Moon SuperS, and Sailor Star, only the first two seasons aired on Indonesian television.

The most popular one was season one. Meanwhile, season two was not as popular as the previous session. This is because television stations often change broadcast hours so that it is difficult for viewers to follow each episode in sequence. Until finally, the broadcast was stopped for no apparent reason. Actually, this was not only happened in Indonesia, but also in several countries like in the United States and Canada. Despite having a high rating, the fifth season of Sailor Stars was never adapted and aired in North America for mysterious decision (Hoskin, 2016).

Furthermore, season two was considered sorrowful and dark. The young Indonesian fans felt uncomfortable and scared. Then, some of them decided to stop watching. Besides, they also starting to grow up. Hence, their taste on entertainment changed to teenage genre like boyband Boyzone and Westlife. Thus, Indonesian are more familiar with the formation of the first five sailors. Nearly two decades after the premiere, Sailor Moon manga re-entered the Indonesian market in 2013 and anime re-aired in 2020.

Sailor Moon is a romantic comedy manga created by Naoko Takeuchi. First released in Japan in 1992. Sailor Moon tells the story of five teenage girls who have the power of the solar system elements which are the moon and planets. These girls are the reincarnations of Princess Serenity and the four Sailor Guardians (also known as Sailor Scouts). In current time, they are known as Pretty Soldiers or inner sailor 
that consist of Usagi Tsukino as Sailor Moon or Princess Serenity, Ami Mizuno as Sailor Mercury, Rei Hino as Sailor Mars, Makoto Kino as Sailor Jupiter, and Minako Aino as Sailor Venus. There is also one important character which is Mamoru Chiba as Tuxedo Mask. Mamoru is Usagi's lover in current time. He also a reincarnation of Prince Endymion, the lover of Princess Serenity in the previous life.

The Pretty Soldiers have two main missions. They have to find the reincarnation of Princess Serenity or the Moon Princess and to find the Silver Crystal. The Silver Crystal depicted has tremendous power. If the Silver Crystal falls into the wrong hands, it can creates chaos in the universe. In the second season of Sailor Moon, other five outer sailors appeared. They are Chibi Usagi (also known as Chibiusa) as Sailor Chibi Moon, Haruka Tenou as Sailor Uranus, Michiru Kaioh as Sailor Neptune, Hotaru Tomoe as Sailor Saturn, Setsuna Meiou as Sailor Pluto. The outer sailor's mission is to protect the Moon Kingdom

After more than two decades since its premiere, Sailor Moon still has loyal fans today. The distribution of Sailor Moon products, both original and fake, still happen, such as clothes, bags, makeup, and knick-knacks. The high audience interest in the classic Sailor Moon made this anime re-air on an Indonesian television station twice, in 2013 and 2020. Sailor Moon's popularity then raises question on how does the Sailor Moon influence Indonesian girls in the 90s so that it still lasts today.

Several studies on Sailor Moon in Indonesia have been conducted. For instance, anime Sailor Moon as a medium for learning Japanese (Soselisa, 2012), use of female language (Hajar, 2016), and cosplay pet using Sailor Moon's character (Wijaya, Pranayama, Yulianto, 2014). However, research on Sailor Moon mostly related to Japanese-language. Thus, to provide a new perspective, I will focus on Sailor Moon's influence in shaping Indonesian girls' generation in the $90 \mathrm{~s}$.

This study was conducted using qualitative methodology in data collection and interviews. The paper was done with online interviews via voice/video call with Sailor Moon fans. To explore other perspective, I also interviewed non-fans and male informants. This research also used literature review from journal and website for secondary sources.

\section{Female as a Superheroes}

Sailor Moon emerged amid the lack of female superheroes for Indonesian girls. 
At that time, the majority of Japanese manga/anime featured a boy as the main character. For example, Dragon Ball, Dash Yankuro, Saint Seiya, Ronin Warriors, Kamen Rider Black, and Detective Conan which focus on male superheroes and the action genre.

"For me, Sailor Moon provided other kids games options besides Power Ranger. Me and other female friends played Sailor Moon role play. We followed the scene that appeared in the episode we just watched. It was fun" (Informant 4, mid 30s, Female).

The presence of Sailor Moon provided a new perspective that female can become super heroes who save the world. Girls also felt that they have female hero representation. After Sailor Moon boomed, many female superheroes manga/anime entered Indonesian market in the 1990s to early 2000s such as Wedding Peach, Magic Knight Rayearth, and Cardcaptor Sakura.

"When I first watched Sailor Moon as a child, I felt happy because I saw powerful girls. Just found out that girls can be strong, too. And from there, I learned that even an underdog like Usagi can have hidden power as Sailor Moon." (Informant 3, mid 30s, Female).

The rise of female superheroes in Indonesian screen through anime had a significant impact on girls because it showed new type of hero. Characters in the Sailor Moon do not only show strong female superheroes. At the same time, the feminine side is still shown through costume, make-up, and story line. Sailor Moon is not immersed in excessive masculinity to display the power of female superheroes. The same style is also seen in the characters Caulifla and Kale from the Dragon Ball Super (Sunil, 2020). Sailor Moon does not drown in the overly masculine female character. Instead, it depicted a strong female character. Interestingly, femininity in Sailor Moon is very dominant from the super hero and the super villain.

\section{Finding Alter Ego in Characters}

Alter ego or alternative self is a concept that states that a person can find another self with a different personality. The existence of the alter ego can be considered as 
a second self, a trusted friend. One of the famous stories of having an alter ego is Beyoncé. Her alter ego, Sasha Fierce, is bold, fabulous, and extremely confident, in contrast to the shy Beyoncé. After helping her through various nervous moments, Beyoncé finally killed her alter ego in 2010 she doesn't need her anymore (McDonald, 2013).

Although it does not have a story like Beyoncé, the informants in this study stated that they found the alter ego of the characters that appeared in Sailor Moon series, especially season one. The selection of the informant's favorite character based on related feeling in ones charater. In addition, their favorite character was also the character they wanted to be.

Usagi Tsukino 月野一うさぎ (also known as Serena Tsukino) is the primary protagonist of Sailor Moon series. Her character depicted as immature, cheerful, and sometimes overtaken with emotion. In other side, she is underachieving, not brilliant, and careless. However, it turned out that, she is the Sailor Moon セーラームーン, the leader of the Sailor Guardians. She also turned out to be the Moon Princess. Usagi's character triggers the Indonesian audiences, that even though you are currently in an underdog circumstance and unnoticed, but actually deep down inside there is a special soul waiting to be found. Through Sailor Moon, it showed that leader is not always the smartest and the prettiest girl in group. Usagi became an 'icon of hope' that anyone can find the power inside themselves to be special.

"I like Usagi because she's the lead character. I think most of children at that time wanted to be the main character. Or maybe just me? Haha. Well, I think Usagi is similar to me. Both of us questioning ourself, our own power. I think this is matter of confidence. To be honest, I wanted to be in the spotlight, but I was not good enough. I was not a popular girl at school. However, Usagi taught me to finds strength in me. From that, I started to believe myself." (Informant 6, late 30s, Female).

Ami Mizuno 水野 亜美 (also known as Amy Anderson) or Sailor Mercury セーラー マーキュリー was the second Sailor Guardians introduced after Usagi. Ami is the smartest among Sailor Guardians with powers based on water. She is a typical smart kid in the class who did not easily make friends. Through Usagi's warmth, Ami began to open up and shows her gentle and sweet character. 
Ami's dream is to become a doctor. In the context of the 90 s, in Indonesia it was still rare for to find female scientists or doctors who were widely known by the public and be the role model for girls. Indonesian society at that time still had the view that girls did not have to get higher education. Because, at the end, women will occupy their domestic role as housewives and take care of the family at home. Thus, most parent taught it was not necessary for girls to have high education. However, through Ami's character, Indonesian girls finally have role model that taught them dare to dream and accomplish high academic achievements.

"Sailor Mercury is calm and gentle. Compared to other characters, she is more mature, gentle, and seems like lovable motherly figure. She likes to give in and a good person. She also smart. The smartest one! At that time, I was comfortable seeing Ami's figure. I can't be like Ami because my nature is opposite to her. But, when I saw Ami, I felt comfortable. I idolize her. I want to be like her." (Informant 4, mid 30s, Female).

Rei Hino 火野レイ (also known as Raven/Raye Hino) or Sailor Mars セーラー マーズ. Possessing the power of fire, Rei is the second Sailor Guardians discoveres by Usagi. She is a type of pretty girl but at the same time has firm personality. Rei is straight forward, and fierce. Rei appearance is Indonesian beauty standard which has bright skin, long black straight hair, slim, and descent height.

"I don't really watch Sailor Moon because it's a girl show. But among all the sailors, I like Mars. She has white skin, long black hair, firm, and beautiful. She's the ideal type of girl." (Informant 1, early 30s, Male)

In the anime, Rei's character is depicted where she became fiery, bold, goes after what she wants, and dares to say no. These characters are considered similar with Makino Tsukushi in Hana Yori Dango. Nevertheless, Rei's perfect physical appearance and independent attitude, he became the favorite character of the Indonesian male audience.

"I think Mars, physically, is the ideal type of woman in Indonesia. 
Most Indonesian men like women with long straight hair because it reflects the feminine side. But at the same time, Mars is bold and independent. Her type is similar to Makino Tsukushi" (Informant 2, late 30s, Male)

In terms of relationship, Rei was the one who confess her feelings to Mamoru in anime version. Back then, it was taboo in Indonesia for girl to confess her feeling first to a boy. However, Rei's character gives a new perspective on what girl can do, in term of relationship.

"I love Sailor Mars. In the past, after watching a few episodes, I became interested in Mars more than the other characters. She is different with Sailor Moon who is crying all the time. Actually, Mars is the opposite of me. I'm craven and shy. Maybe my character is a bit similar to Sailor Moon, but I don't really like her personality. Mars is fierce and courageous. That's why I think, Mars is suitable to be idolized." (Informant 5, mid 30s, Female)

Makoto Kino 木野 まこと(also known as Lita Kino in English version) is a tomboyish and muscular character. As Sailor Jupiter セーラージュピター, Makoto has the power of lightning. Makoto is the tallest among inner Sailor Guardians. Having great physical strength makes her considered a delinquent. This makes her avoided by his female friends. In contrast, Makoto is good at cook and women's handwork. In Indonesia, tomboyish girl often synonymous with boy activities. However, Makoto's character showed the opposite way and depicted that stereotype are not always like that.

"Mako is Sailor Jupiter, right? When I was little, I really liked Mako because her hair was beautiful. I want to have hair like Mako because I have thin hair. Mako is calm, strong, and firm. She has the power of lightning. She is really cool! When I was little, I was afraid of thunder. But since seeing Mako, I've become braver. Mako is good at cooking too. It's very rare that there are strong girls but good at cooking. Unfortunately, the character is rarely shown in anime Sailor Moon. When little, I was upset because I waited for Mako's scene, but 
she rarely appeared." (Informant 7, early 30s, Female)

The disappointment conveyed by informant 7 regarding the lack of Makoto scenes was also the reason for stopping watching what was experienced by informant 10 . Even though she was initially excited to watch the Sailor Moon series, Ami's character, which was rarely highlighted, made her dissatisfied and decided to stop watching Sailor Moon. Even though she claimed not to be a Sailor Moon fan, informant 10 still stated that she still liked Ami's character as an adult. For her, Ami is an inspiration to become a smart and knowledgeable woman.

"I watched it at first, but stopped. I was annoyed with Usagi's character which is too whiny and spoiled. I liked Ami, but she rarely appears. Because of that I stopped watching." (Informant 10, late 30s, Female)

Minako Aino 愛野 美奈子 (also known as Mina Aino) is soft character, beautiful, sociable, popular. Initially, she was known as Sailor V, but when she joined the other Sailor Guardians, her identity changed to Sailor Venus セーラーヴィーナス. Minako represented planet of Venus as well as goddest of love in Roman mythology. Minako represents the planet of Venus as well as goddest of love in Roman mythology. Minako has similarities with Usagi because her duty was to pretend to be the Moon Princess in order to keep her from danger.

Minako is dreaming to be an idol. Back in the 90s, Indonesian parents generally wanted their children to be a doctors, pilot, and engineer. However, Minako's character opens up the option to children that dreams are not only to be a doctor or pilot. Being a celebrity is also a good choice and that is okay.

"Minako is the prettiest. In the past, when me and friends played the Sailor Moon role play, most of us wanted to be Minako. I was sad when Minako was misrecognized as the Moon Princess. For me Minako is really a role model because she is beautiful, girly, but at the same time still looks strong and firm. She is different with Usagi who is a crybaby and must be encouraged by everyone to be brave. I think Minako is more suitable as the Moon Princess." (Informant 8, early 30s, Female) 
In addition to the five Sailor Guardians, the character of Mamoru Chiba 地場衛 also caught the attention of Sailor Moon series fans. Playing the role of Tuxedo Mask タキシード仮面 in present day, Mamoru is the incarnation of Prince Endymion. Mamoru is the first love of Sailor Moon' fans. The character is smart and does not talk much. Mamoru became the ideal male type for Sailor Moon audiences due to his mysteriousness that attracts the attention of many girls.

"Mamoru is mysterious. He is type of a guy who doesn't show his feeling to a girl he likes. Tsundere character. Personally, I don't like a guy who chase a girl and show his feelings too much. For example, asking have you eat or not, bla bla. I prefer a guy like Mamoru who is not nosy, but make me curious. Japanese comics have a lot of male characters like that. When I see a guy, who have a personality like that, I think of Mamoru.” (Informant 3, mid 30s, Female)

\section{Sailor Moon's Value in Shaping Audience's Character}

In my research, I found that the informants agreed that through the Sailor Moon series, they had the courage to open up, be more confident, and start a friendship when they were children. Back then, anime was aired on weekdays afternoon and Sunday. Under the circumstances, they will be discussed the episode together with friends at school on the next day. From that, they had a courage to open up and formed stronger bonds as a friend.

Some of the informants started a girl squad that representing five inner sailors. Their squad consist of five people which has a role as a one character on the Sailor Guardians. Some have a fixed and unchanging role form, but some has a flexible role. They can choose which character they want to be. And it will change the next day.

“At first, I was shy girl. I was often bullied by friends, so I didn't want to interact with other people. I thought, I will be just fine if I don't have friends because I can do things by myself. But since watching Sailor Moon, I've became more confident. Dared to open a conversation with new people. Talked about the Sailor Moon episode that we watched yesterday. Then finally, we formed sailor squad. I was 
Sailor Mars. Having friends was actually fun. I can get to know other from different backgrounds and characters. When the five of us became friends, I felt that friendship was something good." (Informant 5, mid 30s, Female)

The Sailor Moon series also has an influence on increasing reading interest. At first, informants started to read Sailor Moon in manga version. Then, they read various news about Sailor Moon in magazine and tabloid. Interest in reading in a more serious scope also emerged such as the solar system, time travel, and alien.

In addition, the popularity of the Sailor Moon series also increased the interest in drawing, especially manga style. At that time, many children's tabloids provided tutorials on how to draw in manga. For instance, draw from right-to-left, large and sparkling eyes, and pointy chins (Cohn, 2008; Lau, 2013). Some informants also mentioned that they draw Sailor Moon characters and sell to friends.

Lastly, informants also stated that they experienced self-reflection while watching the Sailor Moon series as a child. If the Sailor Guardians have a life mission, they wondering about their own life mission. One informant stated that her Sailor squad often helps friends who sick at school. They thought that they were on a mission like the Sailor Guardians did.

"When I watched Sailor Moon, I thought people who are born in this world have their own life mission. I wondered, what was my life mission? When me and my friends played sailor squad, we acted as if we had a mission. For example, when there were events at school, we immediately helped if schoolmates got sick or fall. When we were done, it felt like mission accomplished. Haha" (Informant 5, mid 30s, Female)

\section{Several Issues on Sailor Moon: Body Image, Reincarnation, Time Travel, Gender Concept, and Queer Character}

Through Sailor Moon, audiences are introduced to several issues. First, body image. Body image is the most criticized issue on the Sailor Moon series by informants. Most 
of characters, or maybe all of them, look gorgeous with V-shape face, large breasts, small waist, and long legs. Body image is not only displayed visually, but also verbally through the scene when Usagi experiences criticism from her friends for gaining weight (Hewlett, 2015). Not only the protagonist, even the villains look slim and skinny. As a child, some informants admitted that they wished to have a body shape like the character in the Sailor Moon series. Informant 5 even went on a diet and drank slimming tea while in elementary school to look skinny like Sailor Guardians.

"The cartoons character that existed and I watched were slim and skinny. When I was in elementary school, I thought I was fat. Mom also thought I was fat. Well maybe because of the comparison was cartoons. The cartoons I watched like Sailor Moon, all have skinny legs and small calves. Meanwhile, my hips were big. Then, Mom gave me slimming tea so I could be slim like the Sailor Guardians. However, one day, Mom's friend told her that small children should not drink slimming tea because it would dry out the uterus. Since then, I stopped drinking slimming tea. After not watching Sailor Moon, I did not feel fat anymore. I ate normally and not afraid of getting fat. In fact, I was not fat." (Informant 5, mid 30s, Female)

Secondly, the concept of reincarnation. In the Sailor Moon series, Usagi and her friends are depicted as the reincarnations of the Princess Serenity and her four guardians. Long ago, the Moon Kingdom existed in ancient times called Silver Millennium era (Sailor Moon Fandom, nd). At that time, the Moon Kingdom and other planets in the Solar System, including Earth, lived in harmony. Even though they have a good relationship, the people of Earth and the Moon should not have a relationship. However, the Princess Serenity and Prince Endymion who was the First Crown Prince of Earth, fell in love.

The love story of Princess Serenity and Prince Endymion aroused the jealousy of Queen Metalia from the Dark Kingdom. She instigated Beryl, an Earth sorceress, to make the people of Earth to fight against the Moon Kingdom. As a result, Prince Endymion, Princess Serenity, and all guardians died in the battle. In the midst of the destruction of the Silver Millennium era, Queen Serenity uses the Silver Crystal to seal the power of the Dark Kingdom. Then, the Queen sent Princess Serenity, Prince 
Endymion, and all guardians into the future. All of them were reincarnated and reborn on Earth in the 20th century.

Even though the Sailor Moon series is just fiction, the concept of reincarnation is something new and bizarre to the 90s Indonesian children, especially Muslim. Indonesia is a Muslim majority country that does not recognize the concept of reincarnation. In Islamic tradition, when a person dies, they will go to the afterlife and take the responsibility of their action during the earthly life. In Islam, belief in rebirth or reincarnation is considered a human desire for immortality and is not compatible with Islam's resurrection in afterlife (Bulğen, 2018). Several informants stated that they became curious about the reincarnation and started discussing it in Islamic class with teacher and friends.

"I first knew reincarnation thing from Sailor Moon. At first, I felt strange because how could someone be born again. Because I'm a Muslim and Islam doesn't teach that. Out of curiosity, I asked my teacher. The funny thing is, we had a discussion about reincarnation during Islamic class. From there, I understand that reincarnation exists in the concept of other culture and believe" (Informant 9, late 30s, Female)

Third, time travel and teleportation. Time travel and teleportation are things that appear in the Sailor Moon series, especially season two. In season two, Meiou Setsuna (Sailor Pluto) is the protector of the space-time door and space-time keys. Her ability to control the time came from his father Chronos, the God of Time. One of Pluto's space-time key was taken by Chibiusa. This key allowed Chibiusa to travel the time and visit Usagi and Mamoru in the past.

Sailor Pluto's powers over time and Chibiusa's ability to travel back in time were interesting scene for young children. Although Islam does not recognize the concept of reincarnation, teleportation and time travel are familiar concepts in the Islamic tradition. The concept of teleportation is known as Tayy al-Ará which means traversing the earth or universe without actually physically moving (Miller, Vandome, and McBrewster, 2011).

In Islam tradition, there are several stories of that indicated teleportation. One of the most famous stories on teleportation in Islam was the Isra' Mi'raj Event. At that event, Prophet Muhammad was flight into other space and outer space by riding 
a Buraq (four-legged animal with wings) in speed of light. The incident occurred in six hours with the distance around 1,500 kilometers (Shahab, 2019). The journey itself started from the Al-Haram Makkah Mosque in Saudi Arabia to the Al-Aqsa Mosque in Palestine. Then, Prophet Muhammad flied from Al-Aqsa Mosque to the Sidratul Muntaha (seven heavens) (Purwanto, 2015). This event is important because in Isra 'Mi'raj the commandment to pray five times a day for Muslims. In modern science, this event can be research through Einstein's theory of relativity of time (Celina \& Suprapto, 2020).

Fourth, gender concept. There are several gender concepts such as gender fluid and non-binary that can be seen from the Sailor Moon series. For instance, the character Haruka Tenou or Sailor Uranus (renamed as Amara Tenou in some English version) who experiences gender fluid or non-exclusive gender identity as female or male. Gender fluid itself is considered as an expression of one's gender which includes aspects of identity and expression (Katz-Wise, 2020). When not in Sailor Guardian form, Haruka is more often seen wearing male clothes and using male language. However, on several occasions, Haruka has also dressed very feminine. In manga version, Sailor Uranus explained as a guardian who possessed the strength of both gender which make her both male and female.

Besides Haruka, another character who has a special gender concept are the Sailor Stars in Sailor Moon season five. Three sailors named Taiki Kou (Star Maker), Seiya Kou (Star Fighter), and Yaten Kou (Star Healer) showed non-binary characteristics because they are able to change their gender from female to male. Non-binary itself is a term that means (and not limited to) : 1) an individual whose gender identity falls between or outside male and female identities, 2) an individual who can experience being a man or woman at separate times, or 3) an individual who does not experience having a gender (Matsuno and Budge, 2017). As non-binary, Sailor Stars has a variety of gender identities and often changes over time. While on Earth and in human form, the Kou brothers take the form of boys. But when they turn into Sailor Stars, they become girls.

"I enjoyed Sailor Moon season one. The other seasons were very confusing and seem too pushy. You know Haruka, right? Also, the latest season, they introduced Sailor Star. So, are they male or female? In normal day, they act like man and wear men's clothes. But, when 
they transform to sailor, they wear miniskirts and heels. Maybe this is what is called nonbinary or gender fluid? So confusing!" (Informant 9, late 30s, Female)

The first season of Sailor Moon did show heterosexual harmony when all the characters were described as having a stable sex and gender. However, after the first season, the Sailor Moon series has blurred the boundaries of sex, sexuality, and gender (Hoskin, 2016). This large amount of gender fluidity has led to censorship in several countries, including Indonesia, to comply with the provisions for child-friendly shows. For instance, Haruka Tenou and Michiru Kaioh were introduced as cousins to avoid confusion among children. Even so, the Sailor Moon series is considered a medium that introduces gender identity and fluid gender expression for the audience (Hoskin, 2016).

Fifth, queer characters. Haruka Tenou (Sailor Uranus) and Michiru Kaiou (Sailor Neptune) are the most famous queer characters in the Sailor Moon series. Haruka's masculine appearance and attitude as well as her male pattern language caused a lot of censorship on her scene in many countries. This attempt was made to blur the relationship between Haruka and Michiru as lovers and make them more compatible as cousins. In the Indonesian context, Haruka and Michiru's relationship sparked confusion among Sailor Moon fans.

In the 90s, the term queer was still not familiar in Indonesian society. However, the terms lesbian and gay are already familiar among audiences. As a young girl, most of informants stated that they were confused about Haruka and Michiru's relationship. At that time, most of informants prefer to believe that Haruka and Michiru were cousins instead of as a lesbian couple. Sailor Moon season two which was getting more complex, darker, and intense made Indonesian fans start to lose interest.

"At first, I was confused when I saw the relationship between Uranus and Neptune. I thought they were friends, but somehow, they were look like lovers. In the anime, they were introduced as cousin, but in the manga, they have romantic relationship. As a child, of course I confused. Maybe they are lesbian? I didn't dare to think that way. I asked my friends, they confused too. We did not dare to ask our parents. Since I did not idolize Uranus and Neptune, I did not think much about it. After growing up, I found out that it was LGBT. There 
is such a thing like queer. Through those characters, I understand more about it. It adds my knowledge." (Informant 8, early 30s, Female)

Indeed, when informants were young, they did not deeply understand with all these issues. However, over time, they understand better with all of these through school and university. They able to figure it out and find the relate example based on the Sailor Moon series content.

\section{Conclusion}

The strong and rooted impact of Sailor Moon in Indonesia can still be seen until nowadays. Some Sailor Moon products have experienced localization, such as the hijab cosplay which often appears at various cosplay events. There was also the hijab-wearing Sailor Moon statue named Sailormoonah by Alifah Rahdini that displayed at Bandung City Park in October 2020. Traces of the Sailor Moon such as an adaptation of the gamis (Arab-style robe for women) can still be found in the market place. In addition, e-card to congratulate Eid-al-Fitr, the Muslim festival marking the end of the fasting month, circulated online.

The presence of Sailor Moon in the midst of the dominance of male superheroes in manga/anime gives its own significance, especially for girls. Previously, female characters were mostly around as companions for male characters, characters that need to be saved, just being eye candy, and even being sexualized. As a strong female character, Sailor Moon subverts the discourse about weak female. Also, female do not need to be masculine just to be a super hero. In Sailor Moon, efforts to eradicate evil and save the world can be done even while wearing a skirt and high heels. Although there are several issues that need to be criticized from Sailor Moon, such as body image, in the end Sailor Moon became a representation of female heroes in the 90s era. To conclude, Sailor Moon is considered a childhood friend which shapes a girl's childhood dreams which is believed that everyone can be anything and found the moon power in themselves. 
参考文献 (Bibliography)

Bulğen, Mehmet. (2018) Reincarnation (Tanāsukh) According to Islam : Comparative, Historical and Contemporary Analyses. ULUM : Journal of Religious Inquiries, 1 (1), pp.127-162.

Celina. F.M \& Suprapto, N. (2020). Study of Relativity Theory of Einstein: The Story of Ashabul Kahf and Isra' Miraj. Studies in Philosophy of Science and Education. 1 (3).

Cohn, Neil. (2008). Japanese Visual Language the Structure of Manga. In Manga: The Essential Reader. pp.2-21. Continuum Books.

Hajar. Nabilla Imarotussuady. (2016). Shuujoshi Wa and No in Anime Sailor Moon. Master Thesis, Universitas Pendidikan Indonesia.

Hewlett, Darrah M. (2015). Anime and Identity: The Reception of Sailor Moon by Adolescent American Fans. Eat Asian Studies Summer Fellows. 1.

Hoskin, Rhea Ashley. (2016). Westernization and The Transmogrification of Sailor Moon. Interalia: Journal of Queer Studies, pp.1-10,

Lau. Chung Yim. (2013). Manga Drawing as Stereotyped Aesthetics. Visual Arts Research, 39 (2), pp.42-53.

Matsuno, Emmie and Budge. Stephanie. L. (2017). Non-binary/Genderqueer Identities : a Critical Review of the Literature. Current Sexual Health Reports, 9(3), pp.116-120.

Miller, de Frederic P., Vandome, Agnes F. \& John McBrewster, John (Eds). (2011). Tay al-Ard: Thaumaturgy, Teleportation, Islam, Islamic philosophy, Sunni, Shia Islam, Sufi, Quran, Abusaeid Abolkheir, Rumi, Al-Khidr. Alphascript Publishing

Purwanto, Agus. (2015). Ayat-Ayat Semesta: Sisi-sisi Al Quran yang terlupakan. Bandung : Mizan.

Shahab. Muhammad bin Ahmad Anies. (2019). Sejengkal lebih dekat dengan Sang Pemberi Syafaat. Ma'had Allijrah Annabawiyah.

Soselisa, Rebecca. (2012). The Use of Anime as a Medium for Learning Japanese Vocabulary. Bachelor Thesis. Universitas Indonesia.

Sunil. David. (2020). The Superwoman Trope - An Analysis on Excessive Masculine Woman Superheroes in Movies. Anime, and TV Shows. International Journal of English Literature and Social Sciences, 5(6). pp.2263-2266.

Wijaya, Christin Ana, Pranayama. Aristarchus, \& Yulianto, Yusuf Hendra. (2014). Perancangan Fotografi Cosplay Pet Karakter Anime yang Tayang di Televisi Lokal pada Tahun 1990 hingga 2000-An. Journal Petra. pp. 1-13.

\section{Websites}

Katz-Wise. Sabra L. (nd) Gender fluidity: What it means and why support matters, Access date : 2021.11.1. 〈htt ps://wnw.health.harvard.edu/blog/gender-fluidity-what-it-means-and-why-support-matters-2020120321544>

McDonald. Soraya Nadia(2013.12.28.) Finally free of Sasha Fierce. Beyoncé is a 'Grown Woman. Washington Po st. Access date : 2021.11.14. 〈https://www.washingtonpost.com/blogs/she-the-people/wp/2013/12/28/fin ally-free-of-sasha-fierce-beyonce-is-a-grown-woman/>

Sailor Moon Fandom(nd) Silver Millenium, Access date : 2021.11.20. 〈https://sailormoon.fandom.com/wiki/Silver_ Millennium〉

\section{INTERVIEWS \& PERSONAL COMMUNICATION}

Informant 1. Male. Early 30s. Japanese Culture Enthusiast. Personal Communication via Phone. 27 August 2021 Informant 2. Male. Late 30s. Japanese Culture Enthusiast. Personal Communication via Phone. 28 August 2021 Informant 3. Female. Mid 30s. Sailor Moon Fans. Online interview via Phone. 24 September 2021 
Informant 4. Female. Mid 30s. Sailor Moon Fans. Online interview via Phone. 24 September 2021 Informant 5. Female. Mid 30s. Sailor Moon Fans. Online interview via Phone. 24 September 2021 Informant 6. Female. Late 30s. Sailor Moon Fans. Online interview via Zoom. 25 September 2021 Informant 7. Female. Early 30s. Sailor Moon Fans. Online interview via Zoom. 25 September 2021 Informant 8. Female. Early 30s. Sailor Moon Fans. Online interview via Video Call. 25 September 2021 Informant 9. Female. Late 30s. Sailor Moon Fans. Online interview via Zoom. 26 September 2021 Informant 10. Female. Late 30s. Non-Fans. Online interview via Video Call. 26 September 2021 